\title{
Response of lactating cows to live yeast supplementation during summer
}

\author{
G. G. S. Salvati, ${ }^{*}$ N. N. Morais Júnior, ${ }^{\star}$ A. C. S. Melo, ${ }^{*}$ R. R. Vilela, ${ }^{*}$ F. F. Cardoso, ${ }^{*}$ M. Aronovich, $\dagger$ \\ R. A. N. Pereira, $\ddagger$ and M. N. Pereira*1 \\ *Universidade Federal de Lavras, Lavras, MG 37200-000, Brazil \\ †Empresa de Pesquisa Agropecuária do Estado do Rio de Janeiro, Rio de Janeiro, RJ 21530-900, Brazil \\ †Empresa de Pesquisa Agropecuária de Minas Gerais, Lavras, MG 37200-000, Brazil
}

\begin{abstract}
Dairy cows experiencing heat stress have reduced intake and increased reliance on glucose, making feeding strategies capable of improving diet digestibility plausible for improving postrumen nutrient flow and performance. The effect of yeast on digestion and performance of lactating cows during the warm summer months of southeastern Brazil was evaluated. Cows were individually fed in tie stalls and temperaturehumidity index was above 68 during $75.6 \%$ of the experiment. Twenty-eight Holstein cows $(207 \pm 87 \mathrm{~d}$ in milk) received a standard diet for $14 \mathrm{~d}$ and then a treatment for $70 \mathrm{~d}$, in a covariate-adjusted, randomized block design with repeated measures over time. Treatments were yeast (Saccharomyces cerevisiae) or control. Yeast was top dressed to the diet in the morning, equivalent to $25 \times 10^{10}$ cfu of live cells and $5 \times$ $10^{10} \mathrm{cfu}$ of dead cells. The diet contained corn silage (37.7\%), Tifton silage (7.1\%), raw soybeans (4.1\%), soybean meal (16.5\%), finely ground corn $(20.7 \%)$, and citrus pulp (11.9\%). Yeast increased milk (26.7 vs. 25.4 $\mathrm{kg} / \mathrm{d}$ ) and solids yield (3.06 vs. $2.92 \mathrm{~kg} / \mathrm{d}$ ), especially lactose. Response in milk yield was consistent over time and started at $\mathrm{d} 5$. The daily intake of digestible $\mathrm{OM}$, total-tract digestibility of nutrients, urinary allantoin excretion, chewing pattern throughout the day, and dry matter intake did not respond to yeast. A trend was observed for increased plasma glucose with yeast (62.9 vs. $57.3 \mathrm{mg} / \mathrm{dL})$, lowered respiratory frequency (48 vs. 56 breaths/min), and increased plasma niacin content (1.31 vs. $1.22 \mu \mathrm{g} / \mathrm{mL}$ ), though cows had similar rectal temperature. Ruminal lactate and butyrate as proportions of ruminal organic acids were reduced by yeast, but no effects on other organic acids, ruminal $\mathrm{pH}$, or protozoa content were detected. Plasma urea $\mathrm{N}$ over $24 \mathrm{~h}$ was increased by yeast. On d 72 to 74 , citrus pulp was abruptly replaced with finely ground
\end{abstract}

Received December 10, 2014.

Accepted February 8, 2015.

${ }^{1}$ Corresponding author: mpereira@dzo.ufla.br corn to induce acidosis. The increased load of starch increased dry matter intake between 0700 and $1300 \mathrm{~h}$, jugular blood partial pressure of $\mathrm{CO}_{2}, \mathrm{HCO}_{3}{ }^{-}$, and base excess, and decreased blood $\mathrm{pH}$ for both treatments. The yeast treatment had a higher blood $\mathrm{pH}$ compared with the control, 7.34, and 7.31, respectively. Yeast supplementation improved lactation performance of dairy cows under heat stress. Improvement in lactation performance apparently involved the regulation of body homeothermia, rather than improved digestibility.

Key words: heat stress, niacin, Saccharomyces cerevisiae, plasma glucose, respiratory frequency

\section{INTRODUCTION}

Heat stress negatively affects productivity and longevity of dairy cows (Kadzere et al., 2002). Advances in management, such as cooling systems (Armstrong, 1994) and nutritional strategies (West, 2003), may attenuate the negative effects of heat stress, but the economic loss due to reduced milk production, reproductive efficiency, and animal health during warm seasons is a major issue for the dairy industry worldwide (St. Pierre et al., 2003).

Reduced lactation performance during heat stress has been attributed to the reduction in DMI of heat-stressed cows (Beede and Collier, 1986). However, reduced DMI seems to account for only 35 to $50 \%$ of the reduction in milk yield under heat stress, whereas the remainder could result from alterations in endocrine profiles and energy metabolism of heat-stressed cows (Rhoads et al., 2009; Wheelock et al., 2010). Heat-stressed cows may be in negative energy balance (NEB; Moore et al., 2005) and have increased energy demand for maintenance (NRC, 1981), due to energy expenditure for homeothermic regulation (Fuquay, 1981), capable of decreasing feed efficiency (Britt et al., 2003). During heat stress, cows are more dependent on glucose as an energy source (Rhoads et al., 2009) and despite the NEB, the mobilization of adipose tissue seems to be reduced in comparison with cows experiencing NEB at a thermoneutral temperature (Shwartz et al., 2009). The response may be related to increased plasma insulin 
levels during heat stress, apparently to spare glucose usage by peripheral tissues (Wheelock et al., 2010).

Heat stress may also decrease rumen $\mathrm{pH}$ and disturb ruminal function (Mishra et al., 1970). Cows in heat stress are more prone to respiratory alkalosis (Schneider et al., 1988), which may reduce $\mathrm{HCO}_{3}{ }^{-}$concentration in saliva (Schneider et al., 1984). In addition, a reduction is found in daily rumination time (Soriani et al., 2013), capable of reducing saliva production. Ruminal motility (Silanikove, 1992), blood flow to the digestive tract (McGuire et al., 1989), as well as digesta fractional passage rate, are reduced in heat-stressed cows (Schneider et al., 1988), increasing the propensity of ruminal acidosis.

Supplementation of live yeast may improve nutrient digestibility (Bitencourt et al., 2011; Ferraretto et al., 2012) and control ruminal pH (Bach et al., 2007). Improvements in DMI, lactation performance, and feed efficiency have been reported in response to yeast supplementation of heat-stressed cows (Bruno et al., 2009; Moallem et al., 2009; Marsola et al., 2010). Shwartz et al. (2009) observed that the supplementation of a mixture of exogenous enzymes and yeast culture reduced rectal temperature of heat-stressed dairy cows, suggesting an action on thermoregulatory functions. Under heat stress, feeding strategies capable of increasing digestive efficiency, such as live yeast supplementation, may increase nutrient flow to the small intestine and dairy cow performance.

The objective of this study was to evaluate the effect of live yeast supplementation on digestion, lactation performance, and physiological variables of dairy cows during the hot summer months of southeastern Brazil.

\section{MATERIALS AND METHODS}

The experiment was conducted from January 9 to April 1, 2012, in an open-walled, sand-bedded, tie-stall barn with fans and high-pressure sprinklers at the Better Nature Research Center, located at Ijaci, Minas Gerais, Brazil (http://www.holandesflamma.com.br/). The protocol was approved by the Federal University of Lavras Bioethic Committee in Utilization of Animals (protocol $n^{\circ} 046 / 14$ ). The barn was located at an altitude of $846 \mathrm{~m}, 21^{\circ} 09^{\prime} 52.41^{\prime \prime} \mathrm{S}$ and $44^{\circ} 55^{\prime} 52.40^{\prime \prime} \mathrm{W}$. Environmental temperature and humidity at the center of the barn was measured at 30-min intervals with a digital thermometer (EasyLog-USB-2-LCD, Lascar Electronics, Salisbury, United Kingdom) $2.5 \mathrm{~m}$ from the floor. The temperature-humidity index (THI) was calculated according to Yousef (1985): THI $=\mathrm{T}+0.36$ $\times \mathrm{DP}+41.2$, where $\mathrm{T}=$ temperature $\left({ }^{\circ} \mathrm{C}\right)$ and $\mathrm{DP}=$ dew point $\left({ }^{\circ} \mathrm{C}\right)$.
Twenty-eight Holsteins $(207 \pm 87$ DIM) were fed a standard diet for $14 \mathrm{~d}$ (covariate period). At the end of the covariate period, cows were paired blocked based on calving order and milk yield, and assigned to 1 of 2 treatments for $10 \mathrm{wk}$. Treatments were yeast ( $\mathrm{Sac}$ charomyces cerevisiae, strain NCYC 996, Procreatin7, Lesaffre Feed Additives, Toluca, Mexico) and control. The yeast product $(10 \mathrm{~g} / \mathrm{d})$ was top dressed to the diet of each cow once per day in the morning. The daily dose of yeast per cow was $25 \times 10^{10} \mathrm{cfu}$ of live cells and $5 \times 10^{10} \mathrm{cfu}$ of dead cells. The composition of the yeast product was $92.3 \% \mathrm{DM}, 45.7 \% \mathrm{CP}$, and $4.4 \%$ ash. The niacin content was $45.12 \mathrm{mg} / 100 \mathrm{~g}$ (VitaFast niacin microbiological assay, R-Biopharm, Darmstadt, Germany) and amino acid composition was (g/100 g): aspartate (3.90), glutamate (3.85), serine (1.38), glycine (1.62), histidine (0.85), arginine (1.54), threonine (2.00), alanine (2.30), proline (1.04), tyrosine (1.33), valine (2.10), methionine (0.54), cysteine (0.51), isoleucine (1.18), leucine (2.09), phenylalanine (1.64), and lysine (3.63). The amino acids were analyzed by HPLC (HP Agilent 1100. Agilent Technologies, Waldbronn, Germany).

The TMR was mixed in a stationary mixer and offered twice daily at approximately 0600 and $1400 \mathrm{~h}$. Individual cow intake was assessed throughout the experiment, by recording the amount of feed offered and orts daily (as-fed basis). Samples of ingredients were collected daily and composite samples made per week. Likewise, ort samples were collected daily and composited per cow per week. Composite samples were dried in forced-air oven at $55^{\circ} \mathrm{C}$ for $72 \mathrm{~h}$ and ground through a 1-mm screen in a Wiley mill (Arthur H. Thomas, Philadelphia, PA). The DM content was determined by drying at $100^{\circ} \mathrm{C}$ for $24 \mathrm{~h}$ and $\mathrm{CP}$ was determined by micro-Kjeldahl analysis (AOAC, 1990). The ether extract (EE) was analyzed according to AOAC (1990) after hydrolysis with hydrochloric acid. Ash was analyzed by incineration at $550^{\circ} \mathrm{C}$ for $8 \mathrm{~h}$. The NDF was analyzed using a TE-149 fiber analyzer (Tecnal Equipamentos para Laboratórios, Piracicaba, Brazil) with amylase and sodium sulfide. Starch was analyzed according to Hall (2009). The NFC fraction was calculated: NFC $=100-(\mathrm{CP}+\mathrm{EE}+$ ash $+\mathrm{NDF})$. Composition of consumed diets is reported in Table 1.

Cows were milked twice daily, at 0430 and $1600 \mathrm{~h}$, and milk yield was recorded daily. Milk samples were obtained weekly on the same $2 \mathrm{~d}$ for 4 consecutive milkings. Solids and MUN content were measured (Laboratório Centralizado da Associação Paranaense de Criadores de Bovinos da Raça Holandesa, Curitiba, Brazil) by infrared analysis (Bentley 2000, Bentley Instruments Inc., Chaska, MN). Milk energy secretion 
Table 1. Composition of the consumed diets on control or yeast treatments

\begin{tabular}{|c|c|c|}
\hline Item & Control & Yeast \\
\hline \multicolumn{3}{|l|}{ Diet ingredient, $\%$ of DM } \\
\hline Corn silage & \multicolumn{2}{|c|}{37.7} \\
\hline Tifton silage & \multicolumn{2}{|c|}{7.1} \\
\hline Raw soybeans & \multicolumn{2}{|c|}{4.1} \\
\hline Soybean meal & \multicolumn{2}{|c|}{16.5} \\
\hline Slow release urea & \multicolumn{2}{|c|}{0.2} \\
\hline Finely ground corn & \multicolumn{2}{|c|}{20.7} \\
\hline Citrus pulp & \multicolumn{2}{|c|}{11.9} \\
\hline Magnesium oxide & \multicolumn{2}{|c|}{0.3} \\
\hline Salt & \multicolumn{2}{|c|}{0.2} \\
\hline Limestone & \multicolumn{2}{|c|}{0.9} \\
\hline Minerals and vitamins ${ }^{1}$ & \multicolumn{2}{|c|}{0.4} \\
\hline \multicolumn{3}{|l|}{ Nutrient composition, \% of DM } \\
\hline $\mathrm{CP}$ & 18.3 & 18.4 \\
\hline $\mathrm{RDP}^{2}$ & 12.0 & 12.0 \\
\hline $\mathrm{RUP}^{3}$ & 6.3 & 6.4 \\
\hline $\mathrm{NDF}$ & 38.0 & 38.1 \\
\hline Ether extract & 4.5 & 4.5 \\
\hline Ash & 6.2 & 6.2 \\
\hline Nonfiber carbohydrates & 32.9 & 33.1 \\
\hline Starch & 26.8 & 26.6 \\
\hline DM, \% of as fed & 43.2 & 43.1 \\
\hline \multicolumn{3}{|l|}{ Particle size distribution, $\%$ of diet } \\
\hline Feed particles > $19 \mathrm{~mm}$, DM basis & \multicolumn{2}{|c|}{19.7} \\
\hline Feed particles 8-19 mm, DM basis & \multicolumn{2}{|c|}{26.0} \\
\hline Feed particles $<8 \mathrm{~mm}$, DM basis & \multicolumn{2}{|c|}{54.3} \\
\hline Feed particles $>19 \mathrm{~mm}$, as-fed basis & \multicolumn{2}{|c|}{13.9} \\
\hline Feed particles 8-19 $\mathrm{mm}$, as-fed basis & \multicolumn{2}{|c|}{20.0} \\
\hline Feed particles $<8 \mathrm{~mm}$, as-fed basis & \multicolumn{2}{|c|}{66.1} \\
\hline
\end{tabular}

${ }^{1} 20.0 \%$ Ca; $15.0 \%$ P; $30.0 \% \mathrm{~S} ; 30.0 \% \mathrm{Mg} ; 100 \mathrm{mg} / \mathrm{kg}$ of Co; $3,000 \mathrm{mg} /$ $\mathrm{kg}$ of $\mathrm{Cu} ; 180 \mathrm{mg} / \mathrm{kg}$ of I; $3,000 \mathrm{mg} / \mathrm{kg}$ of $\mathrm{Mn} ; 12,000 \mathrm{mg} / \mathrm{kg}$ of Zn; $100,000 \mathrm{UI} / \mathrm{kg}$ of vitamin A; $250,000 \mathrm{UI} / \mathrm{kg}$ of vitamin $\mathrm{D}_{3} ; 6,250 \mathrm{UI} /$ $\mathrm{kg}$ of vitamin $\mathrm{E}$.

${ }^{2}$ Rumen degradable protein.

${ }^{3}$ Rumen undegradable protein.

$($ milk E; Mcal/d) was calculated as $[(0.0929 \times \%$ fat $)+$ $(0.0547 \times \%$ protein $)+(0.0395 \times \%$ lactose $)] \times \mathrm{kg}$ of milk (NRC, 2001). ECM was calculated as milk E/0.70 (assumes $0.70 \mathrm{Mcal} / \mathrm{kg}$ for milk with $3.7 \%$ fat, $3.2 \%$ protein, and $4.6 \%$ lactose). Four percent FCM was calculated as $(0.4+15 \times \%$ fat $/ 100) \times \mathrm{kg}$ of milk $(\mathrm{NRC}$, 2001). The BCS (scale of 1 to 5, with 1 being thin and 5 being obese; Wildman et al., 1982) was measured by 3 trained evaluators every $2 \mathrm{wk}$ and the average was used to describe the experimental units. After the morning milking, BW was also measured every 2 wk.

Total-tract apparent digestibility of DM, OM, NDF, and non-NDF OM was determined on d 68 to 70 (wk 10) by total collection of feces in buckets by trained personal. Feces were collected concurrent to defecation during three 8-h sampling periods and weighed. The second and third sampling periods begun $8 \mathrm{~h}$ later than the previous sampling, to avoid a major disturbance to the animals while still representing a 24-h collection period. Fecal aliquots (equal fresh weight basis) were immediately frozen during the collection period and a composite sample was formed. Total urinary output was collected in buckets, simultaneously to fecal sampling, to estimate rumen microbial synthesis based on purine derivate excretion. A $10 \%$ sulfuric acid solution was immediately added to the urine samples (1:9) before refrigeration at $4^{\circ} \mathrm{C}$. Composite urine samples were diluted 1:5 with distilled water and frozen at $-20^{\circ} \mathrm{C}$. Allantoin was analyzed as described by Chen and Gomes (1992).

Simultaneously to fecal and urinary collection, chewing activity was measured by continuous observation of buccal activity of each cow at 5-min intervals for 24 h. Buccal activities recorded were water ingestion, feed ingestion, rumination, and idleness. Chewing time, in minutes per day, was the sum of ingestion and rumination time. Chewing, ingestion, and rumination per unit of DMI were calculated using DMI of the day of chewing evaluation.

Blood samples from the coccygeal vessels were obtained on d 64 (wk 10) to determine plasma urea $\mathrm{N}$ (PUN) and glucose. Samples for PUN were obtained immediately before the first daily feeding and 1, 2, 3, 6 , $9,12,15$, and $21 \mathrm{~h}$ after feeding. The blood, collected in Vacutainer tubes containing EDTA, was immediately refrigerated, centrifuged at 1,000 $\times g$ for $15 \mathrm{~min}$ at room temperature, and the plasma was frozen at $-20^{\circ} \mathrm{C}$. The PUN content was analyzed with a laboratory kit (Urea 500, Doles Reagentes para Laboratórios Ltda., Goiânia, Brazil). Plasma glucose content $12 \mathrm{~h}$ postfeeding was analyzed in samples collected in tubes containing EDTA and sodium fluoride with a laboratory kit (Glicose Enzimática Líquida, Doles Reagentes para Laboratórios Ltda.).

Respiratory frequency was measured at $1400 \mathrm{~h}$ on d 7 of each experimental week, and recorded as the average of 3 consecutive measurements of $30 \mathrm{~s}$ per cow. Rectal temperature was measured at 0700, 1300, and $1900 \mathrm{~h}$ on a hot day during wk 5 and on a cool day during wk 9 with digital thermometers (G-Tech TH186, Onbo Eletronics, Shenzhen, China). During d 34 on wk 5 and d 59 on wk 9, blood samples from the coccygeal vessels were obtained $6 \mathrm{~h}$ after the morning feeding to determine plasma niacin content. Blood was immediately refrigerated, centrifuged at $1,000 \times g$ for $15 \mathrm{~min}$, and the plasma frozen at $-20^{\circ} \mathrm{C}$ for analysis of niacin. Niacin was analyzed with VitaFast niacin microbiological assay (R-Biopharm). The plasma (1.0 $\mathrm{mL}$ ) was added to a sterile $50-\mathrm{mL}$ conical centrifuge tube (227261, Greiner Bio-One, Monroe, NC), and 20 $\mathrm{mL}$ of sterile $20 \mathrm{mM}$ sodium citrate buffer $(\mathrm{pH} 4.5$; C0909, Sigma-Aldrich, St. Louis, MO) was added to the plasma and manually shaken. Taka diastase (300 mg; 86247, Sigma-Aldrich) was added, shaken vigorously, and incubated for $1 \mathrm{~h}$ without light at $37^{\circ} \mathrm{C}$. 
Following incubation, sterile double-distilled $\mathrm{H}_{2} \mathrm{O}(19$ $\mathrm{mL}$ ) was added and samples were heated for $30 \mathrm{~min}$ in a water bath at $95^{\circ} \mathrm{C}$ and shaken at 5-min intervals. Following heating, tubes were chilled quickly to $<30^{\circ} \mathrm{C}$ using an ice bath. The tubes were centrifuged and the supernatant was decanted into sterile tubes. Three separate $150-\mu \mathrm{L}$ samples were pipetted into individual wells coated with Lactobacillus plantarum in a 96-well microtiter plate that was incubated in the dark for $48 \mathrm{~h}$ at $37^{\circ} \mathrm{C}$. Lactobacillus plantarum growth was enhanced as niacin concentration in the medium increased. The assay was read spectrophotometrically for turbidity at 610 to $630 \mathrm{~nm}$.

On d 71, rumen fluid samples were collected through a flexible oro-gastric tube. Samples were collected $12 \pm$ $0.25 \mathrm{~h}$ after the morning feeding. Animals were randomly sampled within block. Ruminal $\mathrm{pH}$ was measured immediately. Total protozoa count was performed according to recommendations of Dehority (1984) and Warner (1962). A rumen sample was instantaneously frozen in liquid $\mathrm{N}$ to suppress fermentation and was kept frozen until preparation for analysis of organic acids by HPLC (LC-10Ai, Shimadzu Corp., Tokyo, Japan). An ion exclusion column from Shimadzu (Shim-pack SCR-101H; $7.9 \mathrm{~mm}$ i.d., $30 \mathrm{~cm}$ long) operated at $50^{\circ} \mathrm{C}$ was used for the chromatographic separation. The mobile phase consisted of $100 \mathrm{mM}$ perchloric acid solution with a flow rate of $0.6 \mathrm{~mL} / \mathrm{min}$. The acids were detected by UV absorbance $(210 \mathrm{~nm})$.

After intensive sampling procedures were concluded in wk 10, citrus pulp in the diet was abruptly substituted by the same amount of finely ground corn on $\mathrm{d}$ 72. This diet was fed for $3 \mathrm{~d}$ to evaluate the response to yeast supplementation under increased ruminal acid load. Jugular blood acid-base balance at 1300 h, intake, milk yield, and the proportion of daily intake occurring from 0700 to $1300 \mathrm{~h}$ were measured on $\mathrm{d}-2$ and -1 (before), and 1,2 , and 3 (after) relative to diet change. Jugular blood acid-base balance was analyzed with an AGS 22 blood gas analyzer (Drake Eletrônica e Comércio Ltda., São José do Rio Preto, Brazil) less than $1 \mathrm{~h}$ after sampling. Blood samples were collected at random within block in heparinized tubes and kept under refrigeration from sampling to analysis.

\section{Statistical Analysis}

Data obtained over time were analyzed as repeated measures with the MIXED procedure of SAS (SAS Institute Inc., Cary, NC). The model contained a continuous covariate effect (measure of the same variable at the end of the covariate period), random block effect (1 to 14), and the fixed effects of treatment (yeast or control), time (experimental week or day), and the interaction of treatment and time. The mean square for cow nested within treatment was used as the error term to test the treatment effect. The model for the period of dietary starch challenge contained the random effect of block (1 to 14), and the fixed effects of treatment (yeast or control), time (before or after the dietary starch challenge), and the interaction of treatment and time. The best covariance structure was defined by the Akaike's information criterion among autoregressive, compound symmetry or unstructured. For variables measured once, the model was block and treatment. Statistical significance and trends were considered at $P$ $\leq 0.05$ and $P>0.05$ to $P \leq 0.10$, respectively.

\section{RESULTS}

The confinement housing system did not eliminate the occurrence of summer heat stress. Throughout the experiment, THI values ranged from 60.5 to 85.1, with a mean of 71.8 (Table 2). Cows were subjected to THI of 68 or greater for $75.6 \%$ of the trial. Figure 1 illustrates the occurrence of THI values during the experiment.

Yeast supplementation increased milk yield by 1.3 $\mathrm{kg} / \mathrm{d}$ and milk solids by $0.14 \mathrm{~kg} / \mathrm{d}$. The positive response in lactation performance was apparently driven by increased lactose secretion (Table 3). Milk yield response to yeast supplementation was consistent for the duration of the experiment (Figure 2), and started at $5 \mathrm{~d}$ of supplementation (Figure 3). Increases in ECM and $4 \%$ FCM were observed in response to yeast, and protein and fat secretions also tended to respond positively (Table 3). Cows fed yeast had increased milk fat content at wk 7, 9, and 10 (Figure 4). Daily DMI was only numerically increased by yeast (Table 3 ). Measures of feed efficiency, BW, BCS, and SCC were similar in

Table 2. Temperature humidity index (THI), temperature $\left({ }^{\circ} \mathrm{C}\right)$, and humidity $(\%)$ in the center of the tie stall

\begin{tabular}{lccc}
\hline Item & $\begin{array}{c}\text { Entire } \\
\text { experiment }^{1}\end{array}$ & Wk $5^{2}$ & Wk $9^{2}$ \\
\hline THI $\geq 68, \%$ of time & 75.6 & 95.8 & 52.1 \\
THI $\geq 72, \%$ of time & 39.6 & 60.4 & 37.5 \\
THI mean & 71.8 & 75.0 & 70.4 \\
THI maximum & 85.1 & 83.2 & 79.8 \\
THI minimum & 60.5 & 67.5 & 63.4 \\
Temperature mean & 23.6 & 26.0 & 22.4 \\
Temperature maximum & 36.0 & 33.5 & 31.0 \\
Temperature minimum & 14.5 & 19.5 & 16.5 \\
Humidity mean & 79.4 & 78.2 & 82.2 \\
Humidity maximum & 98.5 & 97.0 & 97.5 \\
Humidity minimum & 33.0 & 51.0 & 55.5 \\
\hline
\end{tabular}

${ }^{1} 3,408$ recordings for the entire experiment at 30-min intervals.

${ }^{2}$ Values for a day on wk 5 and 9 of rectal temperature recording. 


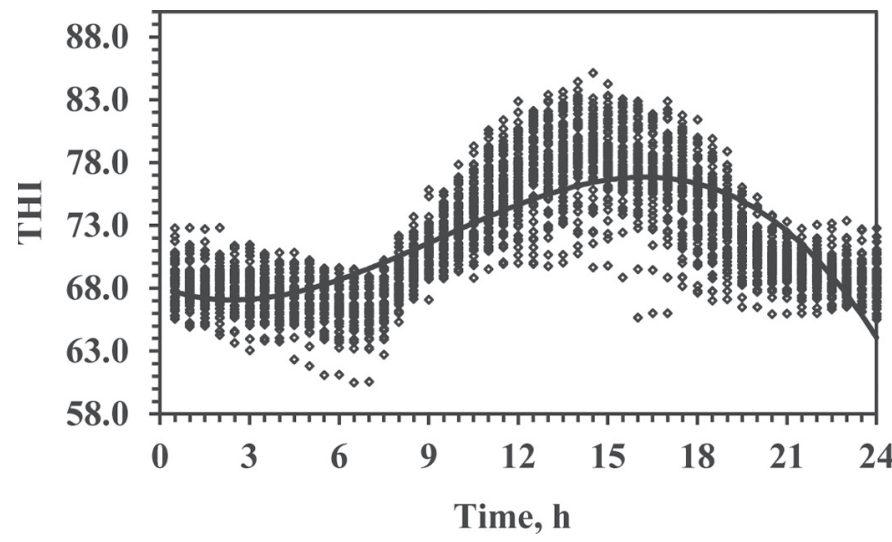

Figure 1. Temperature-humidity index (THI) during the experiment.

both treatments. Yeast improved lactation performance without changing intake or body tissue deposition.

Cows on yeast had consistently lower respiratory frequency throughout the experiment than control (Table 4, Figure 5). Body temperature was not affected by treatment, although during rectal temperature measurement on a hot day (wk 5), a treatment $\times$ time interaction was detected. Body temperature of yeastsupplemented cows was higher than control cows during the day, but lower in the evening (Figure 6). Yeast supplementation apparently facilitated heat dissipation because similar body temperature was observed at lower respiratory frequency. Plasma niacin content was increased (Figure 7) and a trend was observed for increased plasma glucose content in cows supplemented with yeast (Table 4$)$.

Digestion variables did not respond to yeast treatment (Table 5). The daily intake of digestible OM (Table 3 ) and total-tract digestibility of nutrients (Table 5) were only numerically increased by yeast. Rumen microbial yield, estimated by urinary allantoin excretion, and protozoa content in the rumen were similar (Table 5). Rumen fermentation profile was altered by yeast (Table 6 ). Yeast reduced lactate and butyrate as proportions of ruminal organic acids. The acetate to propionate ratio did not differ. Rumen $\mathrm{pH}$ was increased only numerically by the supplement.

Concentration of PUN (Table 4) was increased in yeast-supplemented cows. Yeast supplementation increased PUN throughout the day (Figure 8). Chewing activity and intake pattern were not affected by treatment (Table 7).

The abrupt increase in dietary starch content increased numerically milk yield, had no effect on DMI, and increased the proportion of the daily intake from 0700 to $1300 \mathrm{~h}$ (Table 8). Yeast increased blood $\mathrm{pH}$ before and after the starch challenge. Increased starch content decreased blood $\mathrm{pH}$ and increased blood partial pressure of $\mathrm{CO}_{2}$ and $\mathrm{O}_{2}\left(\mathrm{pCO}_{2}\right.$ and $\left.\mathrm{pO}_{2}\right) \mathrm{HCO}_{3}^{-}$, total $\mathrm{CO}_{2}$, oxygen saturation $\left(\mathrm{SatO}_{2}\right)$, and base excess.

\section{DISCUSSION}

The increase in plasma niacin content in response to yeast supplementation has not been described in

Table 3. Performance of dairy cows on control or yeast treatment (Trt)

\begin{tabular}{lcccccc} 
& & & & \multicolumn{3}{c}{$P$-value } \\
\cline { 5 - 7 } Item & Control & Yeast & SEM & Trt & Time & Trt $\times$ time \\
\hline DMI, kg/d & 19.0 & 19.5 & 0.51 & 0.53 & $<0.01$ & 0.96 \\
DOMI, kg/d & 13.6 & 14.2 & 0.59 & 0.53 & $<0.01$ & 0.17 \\
Milk, kg/d & 25.4 & 26.7 & 0.39 & 0.03 & $<0.01$ & 0.40 \\
ECM, kg/d & 23.0 & 24.4 & 0.45 & 0.05 & 0.02 & 0.70 \\
$4 \%$ FCM, kg/d & 21.7 & 23.1 & 0.47 & 0.05 & 0.04 & 0.65 \\
Fat, kg/d & 0.777 & 0.824 & 0.0178 & 0.09 & 0.07 & 0.48 \\
Fat, \% & 3.06 & 3.17 & 0.057 & 0.22 & $<0.01$ & 0.02 \\
Protein, kg/d & 0.801 & 0.828 & 0.0091 & 0.06 & $<0.01$ & 0.53 \\
Protein, \% & 3.21 & 3.17 & 0.030 & 0.39 & $<0.01$ & 0.74 \\
Lactose, $\mathrm{kg} / \mathrm{d}$ & 1.135 & 1.187 & 0.0146 & 0.03 & $<0.01$ & 0.80 \\
Lactose, \% & 4.52 & 4.51 & 0.025 & 0.76 & $<0.01$ & 0.98 \\
Solids, $\mathrm{kg} / \mathrm{d}$ & 2.921 & 3.062 & 0.0450 & 0.05 & $<0.01$ & 0.80 \\
Solids, \% & 11.67 & 11.72 & 0.078 & 0.64 & $<0.01$ & 0.19 \\
MUN, mg/dL & 15.3 & 15.8 & 0.21 & 0.12 & $<0.01$ & 0.19 \\
Milk/DMI, kg/kg & 1.34 & 1.37 & 0.054 & 0.77 & $<0.01$ & 0.91 \\
ECM/DMI, kg/kg & 1.23 & 1.25 & 0.043 & 0.76 & $<0.01$ & 0.94 \\
BW, kg & 630 & 641 & 5.6 & 0.21 & 0.08 & 0.63 \\
BCS, 1 to 5 & 3.3 & 3.2 & 0.06 & 0.14 & 0.07 & 0.30 \\
Linear SCC, 1 to 9 & 4.7 & 4.3 & 0.33 & 0.41 & 0.70 & 0.87 \\
\hline
\end{tabular}

${ }^{1}$ Digestible OM intake. 


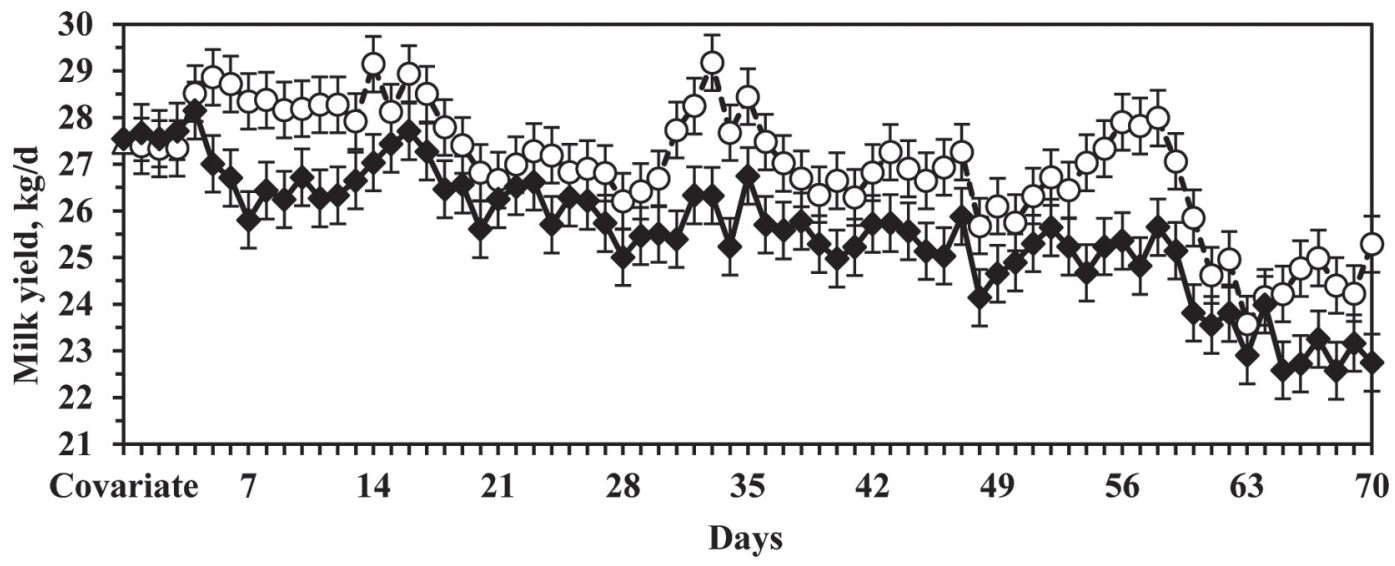

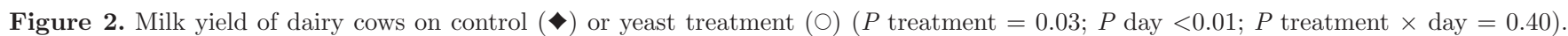
Error bars represent SEM.

Table 4. Plasma glucose, niacin and urea-N content, respiratory frequency, and rectal temperature of dairy cows on control or yeast treatment (Trt)

\begin{tabular}{|c|c|c|c|c|c|c|}
\hline \multirow[b]{2}{*}{ Item } & \multirow[b]{2}{*}{ Control } & \multirow[b]{2}{*}{ Yeast } & \multirow[b]{2}{*}{ SEM } & \multicolumn{3}{|c|}{$P$-value } \\
\hline & & & & Trt & Time & Trt $\times$ time \\
\hline Glucose, ${ }^{1} \mathrm{mg} / \mathrm{dL}$ & 57.3 & 62.9 & 1.13 & 0.09 & & \\
\hline Niacin, ${ }^{2} \mu \mathrm{g} / \mathrm{mL}$ & 1.22 & 1.31 & 0.028 & 0.05 & 0.05 & 0.99 \\
\hline $\mathrm{PUN}, \mathrm{mg} / \mathrm{dL}$ & 14.8 & 16.7 & 0.67 & 0.05 & $<0.01$ & 0.12 \\
\hline Breaths, no./min & 56 & 48 & 2.2 & 0.02 & $<0.01$ & 0.14 \\
\hline Temp wk $5,{ }^{3}{ }^{\circ} \mathrm{C}$ & 38.9 & 38.9 & 0.11 & 0.75 & $<0.01$ & 0.02 \\
\hline Temp wk $9,{ }^{3}{ }^{\circ} \mathrm{C}$ & 38.2 & 38.1 & 0.08 & 0.51 & $<0.01$ & 0.97 \\
\hline
\end{tabular}

${ }^{1}$ Plasma glucose content $12 \mathrm{~h}$ postfeeding on $\mathrm{d} 64$.

${ }^{2}$ Plasma niacin content $6 \mathrm{~h}$ postfeeding on days of wk 5 and 9

${ }^{3}$ Rectal temperature is the mean value of measurements performed at 0700,1300 , and $1900 \mathrm{~h}$ during a hot day (wk 5) and a cool day (wk 9).

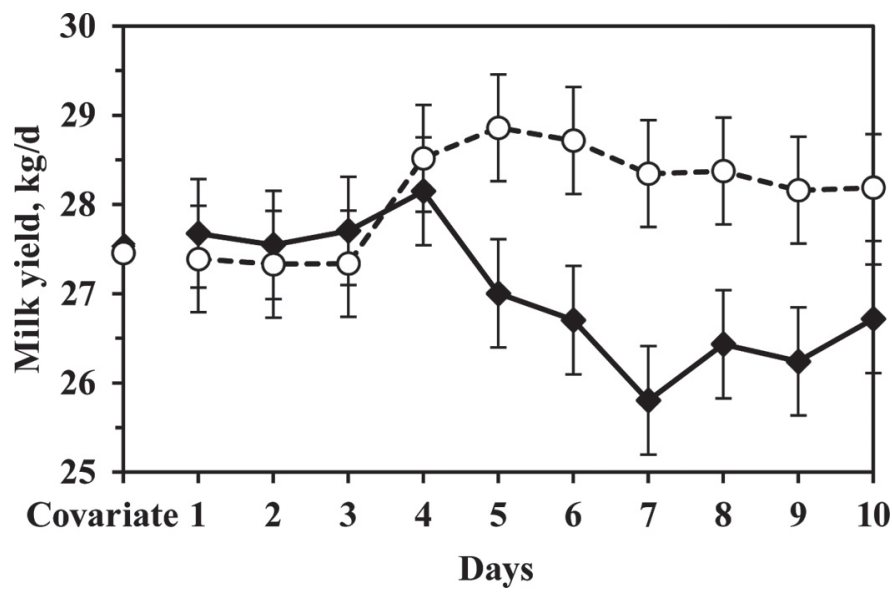

Figure 3. Milk yield of dairy cows during the first $10 \mathrm{~d}$ of the experiment on control $(\checkmark)$ or yeast treatment $(O)(P$-value: treatment $=0.03 ; P$-value: day $<0.01 ; P$-value: treatment $\times$ day $=0.40)$. Error bars represent SEM.

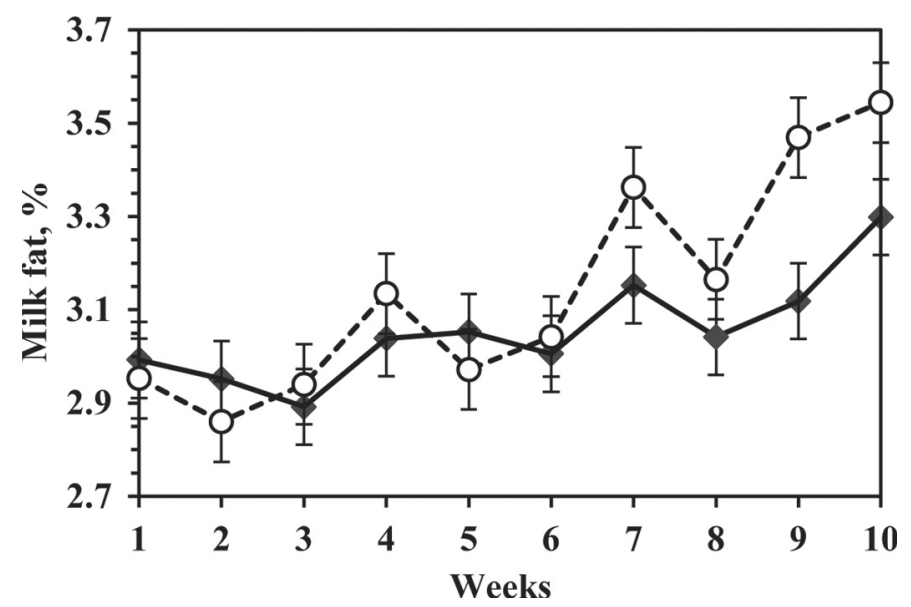

Figure 4. Milk fat percentage of dairy cows on control $(\downarrow)$ or yeast treatment $(O)(P$-value: treatment $=0.22 ; P$-value: week $<0.01$; $P$-value: treatment $\times$ week $=0.02)$. Error bars represent SEM.

Journal of Dairy Science Vol. 98 No. 6, 2015 


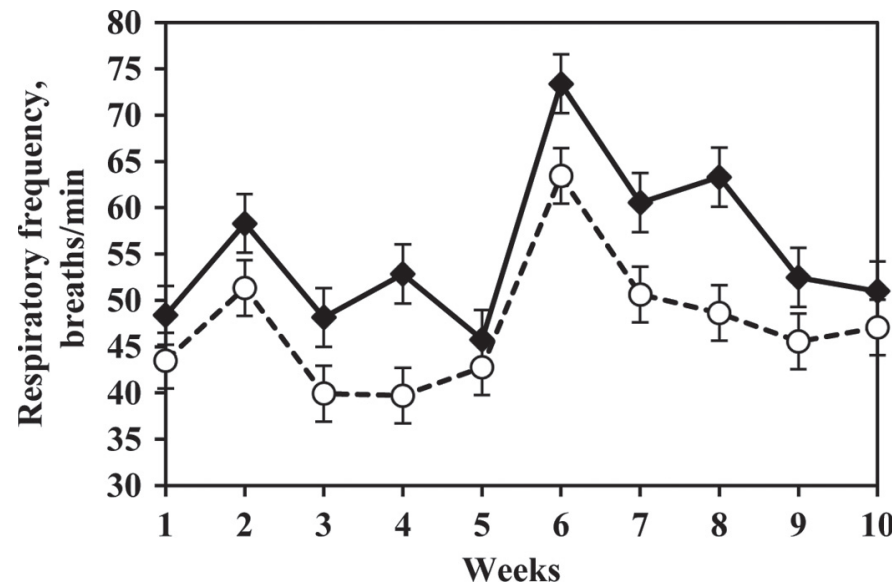

Figure 5. Respiratory frequency of dairy cows on control $(\downarrow)$ or yeast treatment $(O)(P$-value: treatment $=0.02 ; P$-value: week $<0.01$; $P$-value: treatment $\times$ week $=0.14)$. Error bars represent SEM.

the literature. The increase in plasma niacin content of cows supplemented with live yeast approached similar magnitude to the increase of cows supplemented with rumen-protected niacin (Zimbelman et al., 2010; Rungruang et al., 2014). Considering that the niacin content of the yeast product was $45 \mathrm{mg} / 100 \mathrm{~g}$, the daily supplementation of niacin from yeast was $4.5 \mathrm{mg} / \mathrm{cow}$, supposedly too low to induce a biologically meaningful increase in plasma niacin content. Yeast supplementation may have stimulated the synthesis of niacin in the rumen. Ruminal synthesis of niacin ranged from 446 to $1,547 \mathrm{mg} / \mathrm{kg}$ of DMI in dairy cows (Schwab et al., 2006). It has also been shown that the supplementation of dairy cows with yeast and bacteria was capable of increasing the concentration of vitamin $\mathrm{B}_{12}$ in rumen fluid during SARA (Chiquete et al., 2015).

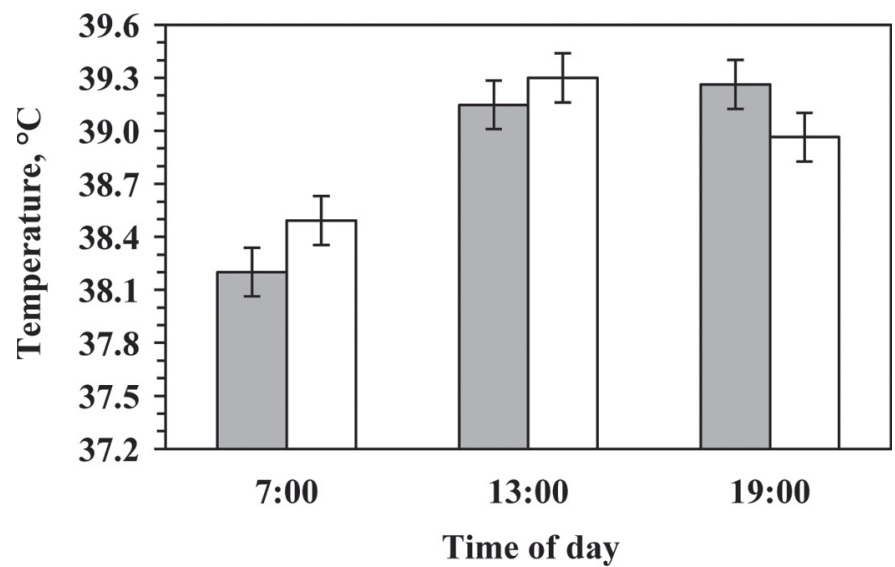

Figure 6. Rectal temperature of dairy cows during wk 5 on control (shaded) or yeast treatment (white) $(P$-value: treatment $=0.75$; $P$-value: hour $<0.01 ; P$-value: treatment $\times$ hour $=0.02)$. Error bars represent SEM.

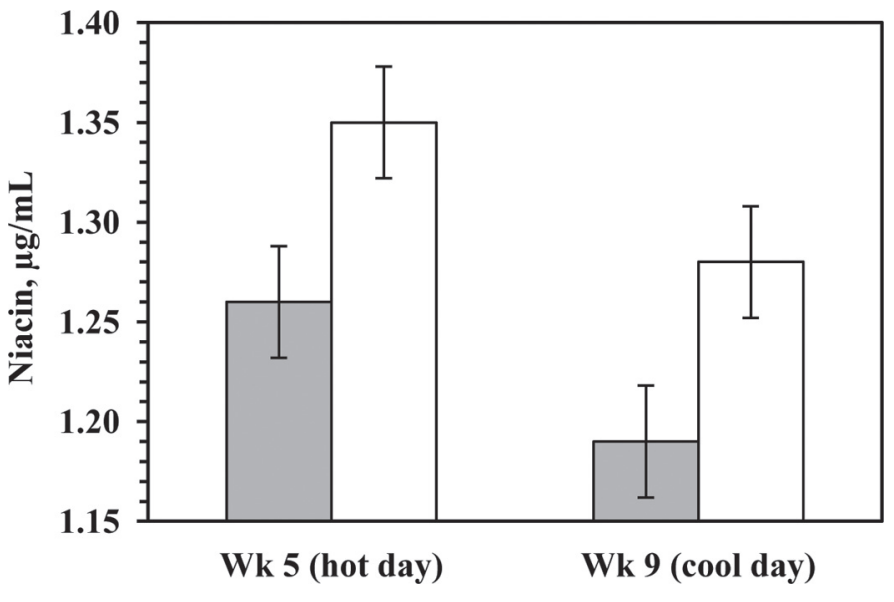

Figure 7. Plasma niacin content $6 \mathrm{~h}$ postfeeding during wk 5 (hot day, temperature-humidity index $=75.0$ ) and wk 9 (cool day, temperature-humidity index $=70.4$ ) for control (shaded) or yeast treatment (white) $(P$-value: treatment $=0.05 ; P$-value: day $=0.05 ; P$-value: treatment $\times$ day $=0.99)$. Error bars represent SEM.

Some strains of $S$. cerevisiae can use tryptophan for the synthesis of nicotinic acid under aerobic conditions (Ahmad and Moat, 1966), similar to some bacteria (Foster and Moat, 1980). Despite the fact that the rumen is considered an anaerobic environment, rumen fluid is not free of oxygen (McArthur and Miltimore, 1962) and live yeasts (Newbold et al., 1996), as well as some other ruminal microorganisms (Ellis et al., 1989), are able to uptake rumen oxygen. Furthermore, in anaerobic conditions, specific bacteria (Foster and Moat, 1980), and some strains of S. cerevisiae, can synthesize nicotinic acid from aspartate and glutamate (Ahmad and Moat, 1966). The diet in this experiment had a higher CP content than was predicted (18.3\% of DM)

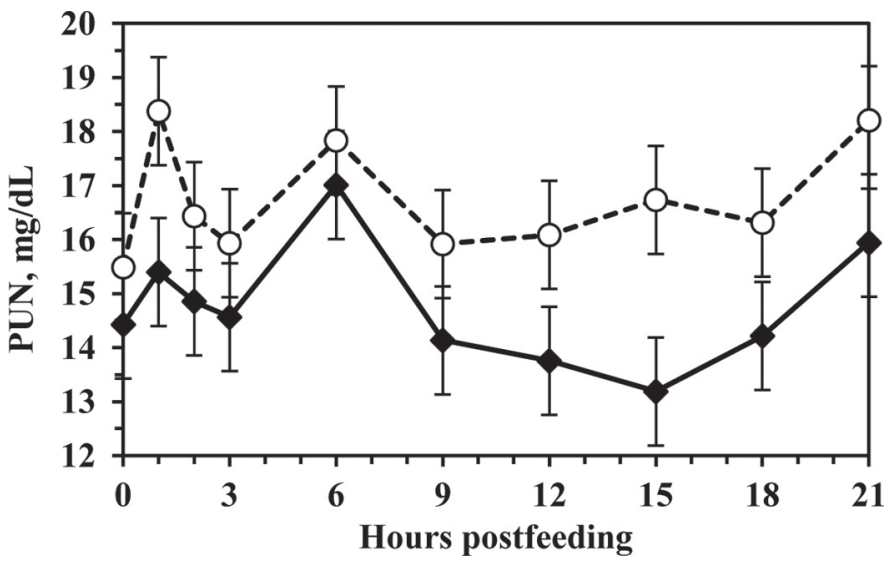

Figure 8. Plasma urea N (PUN) of dairy cows during d 64 on con-

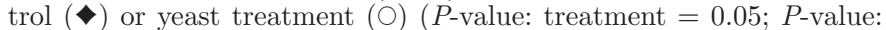
hour $<0.01 ; P$-value: treatment $\times$ hour $=0.12)$. Error bars represent SEM. 
Table 5. Urinary allantoin excretion and total-tract apparent digestibility of nutrients of dairy cows during d 68 to 70 on control or yeast treatment (Trt)

\begin{tabular}{lcccc}
\hline Item & Control & Yeast & SEM & $P$-value \\
\hline Allantoin, mmol/d & 255 & 257 & 13.3 & 0.93 \\
DMD, ${ }^{1} \%$ of intake & 67.7 & 69.2 & 1.38 & 0.45 \\
OMD, ${ }^{2}$ of intake & 71.8 & 72.8 & 1.01 & 0.50 \\
NDFD, ${ }^{3} \%$ of intake & 44.0 & 44.7 & 2.37 & 0.83 \\
Non-NDFOMD ${ }^{4} \%$ of intake & 90.2 & 91.3 & 0.88 & 0.41 \\
StarchD, ${ }^{5} \%$ of intake & 97.4 & 97.1 & 0.18 & 0.39 \\
\hline
\end{tabular}

${ }^{1}$ Dry matter digestibility.

${ }^{2}$ Organic matter digestibility.

${ }^{3}$ Neutral detergent fiber digestibility.

${ }^{4}$ Non-NDF OM digestibility.

${ }^{5}$ Starch digestibility.

and may have supplied enough amino acids to be significantly converted to niacin. Niacin addition to rumen fluid can increase microbial yield (Riddell et al., 1980; Brent and Bartley, 1984). Therefore, the positive effect of yeast on rumen niacin content may be an additional mechanism for the effect of yeast on rumen function.

The beneficial effects of niacin or niacinamide supplementation to cows under heat stress have been described (Muller et al., 1986; Pan et al., 2013). Cows under heat stress had decreased niacin content in plasma (Rungruang et al., 2014), suggesting that niacin supplementation may be required. Niacin can stimulate skin vasodilation (Benyó et al., 2006; Maciejewski-Lenoir et al., 2006) acting on vascular prostaglandin receptors (Cheng et al., 2006) and increase peripheral heat loss in dairy cows (Di Costanzo et al., 1997; Zimbelman et al., 2010). Nitric oxide synthase, a signaling molecule plausibly responsive to niacin, has also been shown to act on cutaneous thermoregulatory blood flow and sweat secretion in humans (Welch et al., 2009). Wrinkle et al. (2012) observed a decrease in respiratory frequency of dairy cows in response to niacin supplementation. The thermoregulatory action of the yeast supplement in this experiment appears to be mediated through increased niacin.

Yeast-supplemented cows had lower respiratory frequency than control cows, but a similar body temperature to control, suggesting they were more efficient at dissipating heat. A similar response has been observed when niacinamide was supplemented to dairy cows under heat stress (Pan et al., 2013). Improved heat dissipation in response to yeast supplementation may have decreased the maintenance energy required for thermoregulation. In wk 5 , the rate of rectal temperature decay in the afternoon was greater for yeast-supplemented cows than for controls. It may explain the trend for increased plasma glucose content in response to yeast supplementation. Di Contanzo et al. (1997) reported an increase in plasma glucose content of dairy cows when niacin was fed during heat stress. Dehghan-Banadaky et al. (2013) also reported an increase in plasma glucose content when dairy cows under heat stress were supplemented with live yeast. Cows in heat stress have increased reliance on glucose as an energy source (Rhoads et al., 2009). Increased glucose availability to the mammary gland, in response to yeast supplementation, apparently increased lactose synthesis, resulting in a positive milk yield response.

The $+1.3 \mathrm{~kg} / \mathrm{d}$ milk yield response to yeast supplementation may be considered of large magnitude compared with what would be expected as a plausible response to this feed additive. Desnoyers et al. (2009), in a meta-analysis on $S$. cerevisiae supplementation to ruminants, estimated a mean milk yield response to yeast of $+0.78 \mathrm{~kg} / \mathrm{d}$, for a $650-\mathrm{kg}$ cow-equivalent. Moallem et al. (2009) also detected $\mathrm{a}+1.5 \mathrm{~kg} / \mathrm{d}$ increase in

Table 6. Ruminal VFA, lactate, $\mathrm{pH}$, and protozoa of dairy cows during d 71 on control or yeast treatment

\begin{tabular}{lcccc}
\hline Item & Control & Yeast & SEM & $P$-value \\
\hline Acetate, \% of total organic acids & 58.4 & 63.6 & 3.28 & 0.28 \\
Propionate, \% of total organic acids & 24.0 & 23.3 & 2.20 & 0.84 \\
Butyrate, \% of total organic acids & 12.6 & 10.5 & 0.99 & 0.05 \\
Isobutyrate, \% of total organic acids & 1.0 & 1.5 & 0.43 & 0.51 \\
Lactate, \% of total organic acids & 4.1 & 2.2 & 0.44 & 0.02 \\
Acetate/propionate & 2.75 & 2.95 & 0.27 & 0.61 \\
pH & 6.35 & 6.44 & 0.093 & 0.48 \\
Protozoa, $\times 10^{4} / \mathrm{mL}$ & 17.6 & 18.0 & 0.72 & 0.62 \\
\hline
\end{tabular}


Table 7. Chewing activity and intake pattern of dairy cows during d 68 to 70 on control or yeast treatment

\begin{tabular}{lcccc}
\hline Item & Control & Yeast & SEM & $P$-value \\
\hline Ingestion, min/d & 284 & 286 & 24.9 & 0.97 \\
Rumination, min/d & 440 & 424 & 26.1 & 0.67 \\
Chewing, min/d & 725 & 710 & 33.0 & 0.76 \\
Ingestion, min/kg of DMI & 17.0 & 16.0 & 1.86 & 0.73 \\
Rumination, min/kg of DMI & 25.4 & 23.7 & 1.27 & 0.35 \\
Chewing, min/kg of DMI & 42.4 & 39.7 & 2.33 & 0.43 \\
Meal size, min & 24.3 & 26.6 & 1.44 & 0.27 \\
Meals per day & 11.7 & 10.7 & 0.54 & 0.21 \\
\hline
\end{tabular}

${ }^{1}$ Chewing = ingestion + rumination.

milk yield when dairy cows were fed live yeast during summer. Bruno et al. (2009) evaluated the supplementation of dairy cows with yeast culture in summer $(723$ cows from 2 farms) and found that yeast supplementation increased milk yield $(+1.2 \mathrm{~kg} / \mathrm{d})$ during the first $130 \mathrm{~d}$ of lactation.

Although positive effects of yeast supplementation on rumen function (Wallace, 1994) and fiber digestibility (Bitencourt et al., 2011; Ferraretto et al., 2012) were expected, this mode of action did not mediate animal responses in this experiment. Total-tract digestibility of nutrients and rumen microbial yield did not respond to yeast, although rumen fermentation profile was modified. Yeast reduced butyrate and lactate as proportions of total organic acids in rumen fluid, but was not capable of increasing $\mathrm{pH}$. Saccharomyces cerevisiae can compete with Streptococcus bovis for sugars (Chaucheyras et al., 1996) and stimulate lactate consumers in the rumen (Nisbet and Martin, 1991; Callaway and Martin, 1997; Rossi et al., 2004). Pinloche et al. (2013) observed increased ruminal abundance of Megasphaera and Selenomonas when live yeast was fed to cows. The response of rumen fermentation profile to yeast supplements lacks consistency. Pinloche et al. (2013) reported increased proportions of propionate and butyrate in rumen fluid in response to yeast, increased proportions of propionate (Erasmus et al., 2005), acetate (Al Ibrahim et al., 2010), and butyrate (Thrune et al., 2009) have been reported, as well the absence of the effect of yeast on rumen fermentation profile (Bitencourt et al., 2011; Ferraretto et al., 2012). Yeast-supplemented cows had higher PUN than control, also observed by Zaworski et al. (2014) in postpartum cows, suggesting increased proteolytic activity in the rumen (Yoon and Stern, 1996). Milk fat content of yeast-supplemented cows was also increased during the final weeks of the experiment. For these finely chopped corn silage diets formulated without sodium bicarbonate, yeast supplementation reduced lactate and butyrate in rumen fluid, suggesting beneficial action on ruminal acidosis.

Yeast did not modulate the response in intake and milk yield during the acidosis induction protocol. The

Table 8. Dry matter intake, milk yield, as-fed intake from 0700 to $1300 \mathrm{~h}$ (7-13 intake), and acid-base balance of the jugular blood $6 \mathrm{~h}$ postfeeding on the last $2 \mathrm{~d}$ of wk 10 (period = before) and during the $3 \mathrm{~d}$ of increased dietary starch content (period $=$ after), on control or yeast treatment $(\mathrm{Trt})^{1}$

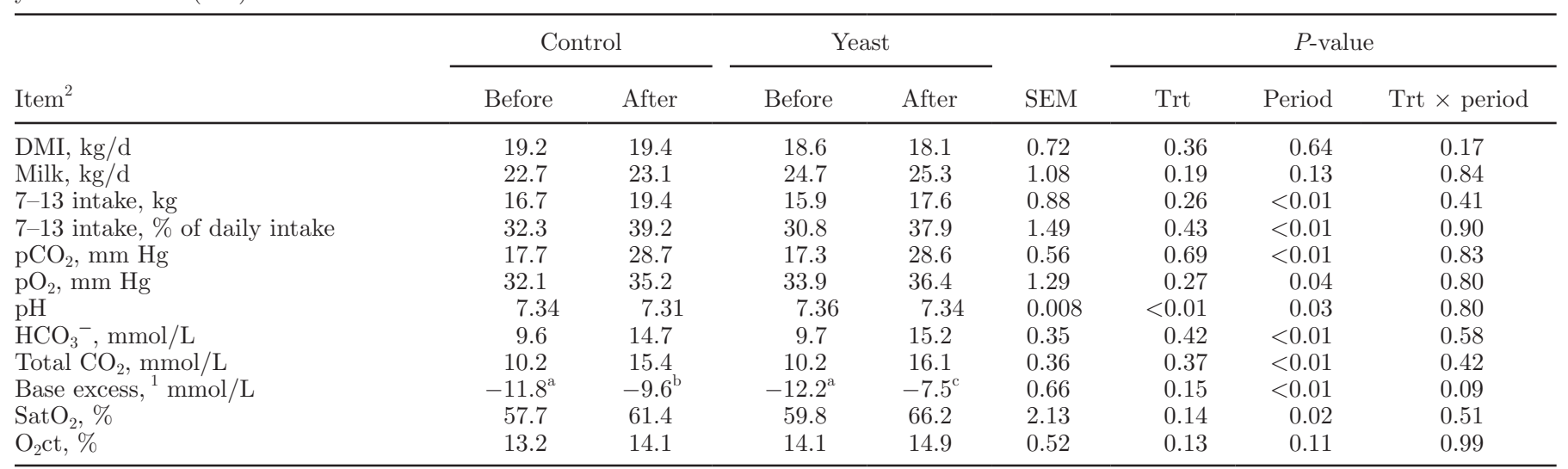

${ }^{\mathrm{a}-\mathrm{c}}$ Means with different letters in superscript differ at $\mathrm{P}<0.05$ (Pairwise t-test of PROC MIXED).

${ }^{1}$ Means within the same line were separated by pairwise $t$-test $(P<0.05$ for PDIFF option of PROC MIXED).

${ }^{2} \mathrm{pCO}_{2}=$ partial pressure of $\mathrm{CO}_{2} ; \mathrm{pO}_{2}=$ partial pressure of $\mathrm{O}_{2} ; \mathrm{SatO}_{2}=\%$ oxygen saturation of hemoglobin; $\mathrm{O}_{2} \mathrm{ct}=\%$ oxygen of the total volume. 
induction of acidosis resulted in detectable changes in intake pattern and blood acid-base indicators. The greater amount of starch increased $\mathrm{pCO}_{2}, \mathrm{HCO}_{3}^{-}$, and base excess, and decreased blood $\mathrm{pH}$, consistent with the occurrence of ruminal acidosis (Morgante et al., 2009; Gianesella et al., 2010). Li et al. (2012) also reported an increase in $\mathrm{pCO}_{2}$ during SARA; however, no difference was found in blood $\mathrm{pH}$.

Cows in both treatments had blood $\mathrm{pH}$ values below 7.35 during the dietary starch challenge, which is considered an indication of metabolic acidosis (Owens et al., 1998). Nevertheless, yeast supplementation increased blood $\mathrm{pH}$ before and during the challenge. Blood base excess was also less negative for yeastsupplemented cows when dietary starch content was abruptly increased. Yeast supplementation apparently had beneficial effects on metabolic acidosis, a plausible additional mode of action to explain the positive response in lactation performance.

We did not detect responses in chewing and eating behavior of heat-stressed dairy cows to yeast supplementation. It has been suggested that yeast supplements can modulate the pattern of intake in dairy cows and are capable of promoting stabilization of ruminal $\mathrm{pH}$. Bach et al. (2007) reported an increase in the frequency of daily meals for cows supplemented with live yeast. DeVries and Chevaux (2014) observed that cows supplemented with yeast had shorter intermeal intervals, translating to cows tending to have more meals, which tended to be smaller in size. Yeast-supplemented cows also tended to ruminate longer, have lower mean ruminal temperature, and spend less time with rumen temperature above $39.0^{\circ} \mathrm{C}$. In theory, a more stable ruminal temperature can facilitate heat dissipation under heat stress.

\section{CONCLUSIONS}

Yeast supplementation improved lactation performance of dairy cows under heat stress. The mechanism apparently involved the regulation of body homeothermia and increased glucose availability for the synthesis of lactose by the mammary gland. Increased plasma niacin content in yeast-supplemented cows was a plausible mediator. Yeast also attenuated metabolic acidosis during a starch challenge and reduced lactate and butyrate proportions in rumen fluid, suggesting positive action on acidosis control.

\section{ACKNOWLEDGMENTS}

Authors are grateful to Lesaffre Feed Additives for partially funding this project, the Brazilian Federal Agency for Post-graduate Education (CAPES), and members of Grupo do Leite of the Federal University of Lavras, specifically Rafael Caputo Oliveira, Willian Pereira dos Santos, Naina Magalhães Lopes, and Igor Gonçalves de Souza Salvati, for their help during data collection and laboratory analysis.

\section{REFERENCES}

Ahmad, F., and A. G. Moat. 1966. Nicotinic acid biosynthesis in prototrophs and tryptophan auxotrophs of Saccharomyces cerevisiae. J. Biol. Chem. 241:775-780.

Al Ibrahim, R. M., A. K. Kelly, L. O'Grady, V. P. Gath, C. McCarney, and F. J. Mulligan. 2010. The effect of body condition score at calving and supplementation with Saccharomyces cerevisiae on milk production, metabolic status, and rumen fermentation of dairy cows in early lactation. J. Dairy Sci. 93:5318-5328.

AOAC. 1990. Official Methods of Analysis. 15th ed. Assoc. Off. Anal. Chem., Arlington, VA.

Armstrong, D. V. 1994. Heat stress interaction with shade and cooling. J. Dairy Sci. 77:2044-2050.

Bach, A., C. Iglesias, and M. Devant. 2007. Daily rumen pH pattern of loose-housed dairy cattle as affected by feeding pattern and live yeast supplementation. Anim. Feed Sci. Technol. 136:146-153.

Beede, D. K., and R. J. Collier. 1986. Potential nutritional strategies for intensively managed cattle during thermal stress. J. Anim. Sci. 62:543-554.

Benyó, Z., A. Gille, C. L. Bennett, B. E. Clausen, and S. Offermanns. 2006. Nicotinic acid-induced flushing is mediated by activation of epidermal Langerhans cells. Mol. Pharmacol. 70:1844-1849.

Bitencourt, L. L., J. R. M. Silva, B. M. L. Oliveira, G. S. Dias Júnior, F. Lopes, S. Siécola Júnior, O. F. Zacaroni, and M. N. Pereira. 2011. Diet digestibility and performance of dairy cows supplemented with live yeast. Sci. Agric. 68:301-307.

Brent, B. E., and E. E. Bartley. 1984. Thiamin and niacin in the rumen. J. Anim. Sci. 59:813-822.

Britt, J. S., R. C. Thomas, N. C. Spear, and M. B. Hall. 2003. Efficiency of converting nutrient dry matter to milk in Holstein herds. J. Dairy Sci. 86:3796-3801.

Bruno, R. G. S., H. M. Rutigliano, R. L. Cerri, P. H. Robinson, and J. E. P. Santos. 2009. Effect of feeding Saccharomyces cerevisiae on performance of dairy cows during summer heat stress. Anim. Feed Sci. Technol. 150:175-186.

Callaway, E. S., and S. A. Martin. 1997. Effects of a Saccharomyces cerevisiae culture on ruminal bacteria that utilize lactate and digest cellulose. J. Dairy Sci. 80:2035-2044.

Chaucheyras, F., G. Fonty, P. Gouet, G. Bertin, and J. M. Salmon. 1996. Effects of a strain of Saccharomyces cerevisiae (Levucell ${ }^{\circledR}$ $\mathrm{SC}$ ), a microbial additive for ruminants, on lactate metabolism in vitro. Can. J. Microbiol. 42:927-933.

Chen, X. B., and M. J. Gomes. 1992. Estimation of microbial protein supply to sheep and cattle based on urinary excretion of purine derivatives: An overview of technical details. Int. Feed Res. Unit, Occasional Publ. Rowett Research Institute, Aberdeen, United Kingdom.

Cheng, K., T. J. Wu, K. K. Wu, C. Sturino, K. Metters, K. Gottesdiener, S. D. Wright, Z. Wang, G. Oineill, E. Lai, and M. G. Waters. 2006. Antagonism of the prostaglandin D2 receptor 1 suppresses nicotinic acid-induced vasodilation in mice and humans. Proc. Natl. Acad. Sci. USA 103:6682-6687.

Chiquette, J., J. Lagrost, C. L. Girard, G. Talbot, S. Li, J. C. Plaizier, and I. K. Hindrichsen. 2015. Efficacy of the direct-fed microbial Enterococcus faecium alone or in combination with Saccharomyces cerevisiae or Lactococcus lactis during induced subacute ruminal acidosis. J. Dairy Sci. 98:190-203.

Dehghan-Banadaky, M., M. Ebrahimi, R. Motameny, and S. R. Heidaria. 2013. Effects of live yeast supplementation on mid-lactation dairy cows performances, milk composition, rumen digestion and plasma metabolites during hot season. J. Appl. Anim. Res. 41:137-142. 
Dehority, B. A. 1984. Evaluation of subsampling and fixation procedures used for counting rumen protozoa. Appl. Environ. Microbiol. $48: 182-185$.

Desnoyers, M., S. Giger-Reverdin, G. Bertin, C. Duvaux-Ponter, and D. Sauvant. 2009. Meta-analysis of the influence of Saccharomyces cerevisiae supplementation on ruminal parameters and milk production of ruminants. J. Dairy Sci. 92:1620-1632.

DeVries, T. J., and E. Chevaux. 2014. Modification of the feeding behavior of dairy cows through live yeast supplementation. J. Dairy Sci. 97:6499-6510.

Di Costanzo, A., J. N. Spain, and D. E. Spiers. 1997. Supplementation of nicotinic acid for lactating Holstein cows under heat stress conditions. J. Dairy Sci. 80:1200-1206.

Ellis, J. E., A. G. Williams, and D. Lloyd. 1989. Oxygen consumption by ruminal microorganisms: Protozoal and bacterial contributions. Appl. Environ. Microbiol. 55:2583-2587.

Erasmus, L. J., P. H. Robinson, A. Ahmadi, R. Hinders, and J. E. Garrett. 2005. Influence of prepartum and postpartum supplementation of a yeast culture and monensin, or both, on ruminal fermentation and performance of multiparous dairy cows. Anim. Feed Sci. Technol. 122:219-239.

Ferraretto, L. F., R. D. Shaver, and S. J. Bertics. 2012. Effect of dietary supplementation with live-cell yeast at two dosages on lactation performance, ruminal fermentation, and total tract nutrient digestibility in dairy cows. J. Dairy Sci. 95:4017-4028.

Foster, J. W., and A. G. Moat. 1980. Nicotinamide adenine dinucleotide biosynthesis and pyridine nucleotide cycle metabolism in microbial systems. Microbiol. Rev. 44:83-105.

Fuquay, J. W. 1981. Heat stress as it affects production. J. Anim. Sci. 52:164-174.

Gianesella, M., M. Morgante, C. Cannizzo, A. Stefani, P. Dalvit, V. Messina, and E. Giudice. 2010. Subacute ruminal acidosis and evaluation of blood gas analysis in dairy cow. Vet. Med. Int. 2010:1-4.

Hall, M. B. 2009. Analysis of starch, including maltooligosaccharides, in animal feeds: A comparison of methods and a recommended method for AOAC collaborative study. J. Assoc. Off. Anal. Chem. 92:42-49.

Kadzere, C. T., M. R. Murphy, N. Silanikove, and E. Maltz. 2002. Heat stress in lactating dairy cows: A review. Livest. Prod. Sci. 77:59-91.

Li, S., G. N. Gozho, N. Gakhar, E. Khafipour, D. O. Krause, and J. C. Plaizier. 2012. Evaluation of diagnostic measures for subacute ruminal acidosis in dairy cows. Can. J. Anim. Sci. 92:353-364.

Maciejewski-Lenoir, D., J. G. Richman, Y. Hakak, I. Gaidarov, D. P. Behan, and D. T. Connolly. 2006. Langerhans cells release prostaglandin D2 in response to nicotinic acid. J. Invest. Dermatol. 126:2637-2646.

Marsola, R. S., M. G. Favoreto, F. T. Silvestre, J. C. Shin, N. Walker, A. Adesogan, C. R. Staples, and J. E. P. Santos. 2010. Effect of feeding live yeast on performance of Holstein cows during summer. J. Dairy Sci. 93(E-Suppl. 1):432. (Abstr.)

McArthur, J. M., and J. E. Miltimore. 1961. Rumen gas analysis by gas-solid chromatography. Can. J. Anim. Sci. 41:187-196.

McGuire, M. A., D. K. Beede, M. A. DeLorenzo, C. J. Wilcox, G. B. Huntington, C. K. Reynolds, and R. J. Collier. 1989. Effects of thermal stress and level of feed intake on portal plasma flow and net fluxes of metabolites in lactating Holstein cows. J. Anim. Sci. 67:1050-1060.

Mishra, M., F. A. Martz, R. W. Stanley, H. D. Johnson, J. R. Campbell, and E. Hilderbrand. 1970. Effect of diet and ambient temperature-humidity on ruminal $\mathrm{pH}$, oxidation reduction potential, ammonia and lactic acid in lactating cows. J. Anim. Sci. 30:10231028.

Moallem, U., H. Lehrer, L. Livshitz, M. Zachut, and S. Yakoby. 2009. The effects of live yeast supplementation to dairy cows during the hot season on production, feed efficiency, and digestibility. J. Dairy Sci. 92:343-351.

Moore, C. E., J. K. Kay, M. J. VanBaale, R. J. Collier, and L. H. Baumgard. 2005. Effect of conjugated linoleic acid on heat stressed Brown Swiss and Holstein cattle. J. Dairy Sci. 88:1732-1740.
Morgante, M., M. Gianesella, S. Casella, L. Ravarotto, C. Stelletta, and E. Giudice. 2009. Blood gas analyses, ruminal and blood pH, urine and fecal $\mathrm{pH}$ in dairy cows during subacute ruminal acidosis. Comp. Clin. Pathol. 18:229-232.

Muller, L. D., A. J. Heinrichs, J. B. Cooper, and Y. H. Atkin. 1986. Supplemental niacin for lactating cows during summer feeding. J. Dairy Sci. 69:1416-1420.

NRC. 1981. Effect of Environment on Nutrient Requirements of Domestic Animals. Natl. Acad. Press, Washington, DC.

NRC. 2001. Nutrient Requirements of Dairy Cattle. 7th rev. ed. Natl. Acad. Sci., Washington, DC.

Newbold, C. J., R. J. Wallace, and F. M. McIntosh. 1996. Mode of action of the yeast Saccharomyces cerevisiae as a feed additive for ruminants. Br. J. Nutr. 76:249-261.

Nisbet, D. J., and S. A. Martin. 1991. Effect of a Saccharomyces cerevisiae culture on lactate utilization by the ruminal bacterium Selenomonas ruminantium. J. Anim. Sci. 69:4628-4633.

Owens, F. N., D. S. Secrist, W. J. Hill, and D. R. Gill. 1998. Acidosis in cattle: A review. J. Anim. Sci. 76:275-286.

Pan, L. D. P. Bu, J. Q. Wang, J. B. Cheng, X. Z. Sun, and W. Liu. 2013. Effects of supplemental niacinamide on lactation performance and rumen fermentation of Holstein cows under heat stress. J. Dairy Sci. 96(E-Suppl. 1):503. (Abstr.)

Pinloche, E., N. McEwan, J.-P. Marden, C. Bayourthe, E. Auclair, and C. J. Newbold. 2013. The effects of a probiotic yeast on the bacterial diversity and population structure in the rumen of cattle. PLoS ONE 8:e67824.

Rhoads, M. L., R. P. Rhoads, M. J. Van Baale, R. J. Collier, S. R. Sanders, W. J. Weber, B. A. Crooker, and L. H. Baumgard. 2009. Effects of heat stress and plane of nutrition on lactating Holstein cows: I. Production, metabolism, and aspects of circulating somatotropin. J. Dairy Sci. 92:1986-1997.

Riddell, D. O., E. E. Bartley, and A. D. Dayton. 1980. Effect of nicotinic acid on rumen fermentation in vitro and in vivo. J. Dairy Sci. $63: 1429-1436$

Rossi, F., A. D. Luccia, D. Vincenti, and P. S. Cocconcelli. 2004. Effects of peptide fractions from Saccharomyces cerevisiae on growth and metabolism of the ruminal bacteria Megasphaera elsdenii. Anim. Res. 53:177-186.

Rungruang, S., J. L. Collier, R. P. Rhoads, L. H. Baumgard, M. J. de Veth, and R. J. Collier. 2014. A dose-response evaluation of rumen-protected niacin in thermoneutral or heat stress lactating Holstein cows. J. Dairy Sci. 97:5023-5034.

Schneider, P. L., D. K. Beede, and C. J. Wilcox. 1988. Nycterohemeral patterns of acid-base status, mineral concentrations and digestive function of lactating cows in natural or chamber heat stress environments. J. Anim. Sci. 66:112-125.

Schneider, P. L., D. K. Beede, C. J. Wilcox, and R. J. Collier. 1984 Influence of dietary sodium and potassium bicarbonate and total potassium on heat-stressed lactating dairy cows. J. Dairy Sci. 67:2546-2553.

Schwab, E. C., C. G. Schwab, R. D. Shaver, C. L. Girard, D. E. Putnam, and N. L. Whitehouse. 2006. Dietary forage and nonfiber carbohydrate contents influence B-vitamin intake, duodenal flow, and apparent ruminal synthesis in lactating dairy cows. J. Dairy Sci. 89:174-187.

Shwartz, G., M. L. Rhoads, K. A. Dawson, M. J. VanBaale, R. P. Rhoads, and L. H. Baumgard. 2009. Effects of a supplemental yeast culture on heat stressed lactating Holstein cows. J. Dairy Sci. 92:935-942.

Silanikove, N. 1992. Effects of water scarcity and hot environment on appetite and digestion in ruminants: A review. Livest. Prod. Sci. 30:175-194.

Soriani, N., G. Panella, and L. Calamari. 2013. Rumination time during the summer season and its relationships with metabolic conditions and milk production. J. Dairy Sci. 96:5082-5094.

St. Pierre, N. R., B. Cobanov, and G. Schnitkey. 2003. Economic losses from heat stress by US livestock industries. J. Dairy Sci. 86 (E Suppl.):E52-E77. 
Thrune, M., A. Bach, M. Ruiz-Moreno, M. D. Stern, and J. G. Linn. 2009. Effects of Saccharomyces cerevisiae on ruminal $\mathrm{pH}$ and microbial fermentation in dairy cows. Livest. Sci. 124:261-265.

Wallace, R. J. 1994. Ruminal microbiology, biotechnology, and ruminant nutrition: Progress and problems. J. Anim. Sci. 72:29923003.

Warner, A. C. 1962. Enumeration of rumen microorganisms. J. Gen. Microbiol. 28:119-128.

Welch, G., K. M. Foote, C. Hansen, and G. W. Mack. 2009. Nonselective NOS inhibition blunts the sweat response to exercise in a warm environment. J. Appl. Physiol. 106:796-803.

West, J. W. 2003. Effects of heat-stress on production in dairy cattle. J. Dairy Sci. 86:2131-2144.

Wheelock, J. B., R. P. Rhoads, M. J. VanBaale, S. R. Sanders, and L. H. Baumgard. 2010. Effects of heat stress on energetic metabolism in lactating Holstein cows. J. Dairy Sci. 93:644-655.

Wildman, E. E., G. M. Jones, P. E. Wagner, R. L. Boman, H. F. Troutt, and T. N. Lesch. 1982. A dairy-cow body condition scoring system and its relationship to selected production characteristics. J. Dairy Sci. 65:495-501.
Wrinkle, S. R., P. H. Robinson, and J. E. Garrett. 2012. Niacin delivery to the intestinal absorptive site impacts heat stress and productivity responses of high producing dairy cows during hot conditions. Anim. Feed Sci. Technol. 175:33-47.

Yoon, I. K., and M. D. Stern. 1996. Effects of Saccharomyces cerevisiae and Aspergillus oryzae on ruminal fermentation in dairy cows. J. Dairy Sci. 79:411-417.

Yousef, M. K. 1985. Stress Physiology in Livestock. 1st ed. CRC Press Inc., Boca Raton, FL.

Zaworski, E. M., C. M. Shriver-Munsch, N. A. Fadden, W. K. Sanchez, I. Yoon, and G. Bobe. 2014. Effects of feeding various dosages of Saccharomyces cerevisiae fermentation product in transition dairy cows. J. Dairy Sci. 97:3081-3098.

Zimbelman, R. B., L. H. Baumgard, and R. J. Collier. 2010. Effects of encapsulated niacin on evaporative heat loss and body temperature in moderately heat-stressed lactating Holstein cows. J. Dairy Sci. 93:2387-2394. 